\title{
RECONSTRUCTION OF BROWN BEAR POPULATION DYNAMICS IN SLOVENIA IN THE PERIOD 1998-2019: A NEW APPROACH COMBINING GENETICS AND LONG-TERM MORTALITY DATA REKONSTRUKCIJA POPULACIJSKE DINAMIKE RJAVEGA MEDVEDA V SLOVENIJI V OBDOBJU 1998-2019: NOV PRISTOP NA OSNOVI GENETSKIH OCEN IN DOLGOLETNEGA NIZA PODATKOV O SMRTNOSTI
}

\author{
Klemen JERINA ${ }^{1}$, Andrés ORDIZ ${ }^{2,3}$ \\ (1) University of Ljubljana, Biotechnical Faculty, Department of Forestry and Renewable Forest Resources, klemen.jerina@bf.uni-lj.si \\ (2) University of Ljubljana, Biotechnical Faculty, Department of Forestry and Renewable Forest Resources, andres.ordiz@gmail.com \\ (3) Norwegian University of Life Sciences, Faculty of Environmental Sciences and Natural Resource Management
}

\begin{abstract}
Reliable data and methods for assessing changes in wildlife population size over time are necessary for management and conservation. For most species, assessing abundance is an expensive and labor-intensive task that is not affordable on a frequent basis. We present a novel approach to reconstructing brown bear population dynamics in Slovenia in the period 1998-2019, based on the combination of two CMR non-invasive genetic estimates (in 2007 and 2015) and long-term mortality records, to show how the latter can help the study of population dynamics in combination with point-in-time estimates. The spring (i.e. including newborn cubs) population size estimate was 383 (CI: 336-432) bears in 1998 and 971 (CI: 825-1161) bears in 2019. In this period, the average annual population growth rate was $4.5 \%$. The predicted population size differed by just $7 \%$ from the non-invasive genetic size estimate after eight years, suggesting that the method is reliable. It can predict the evolution of the population size under different management scenarios and provide information on key parameters, e.g. background mortality and the sex- and age-structure of the population. Our approach can be used for several other wildlife species, but it requires reliable mortality data over time.
\end{abstract}

Key words: genetic estimates of population size, mortality records, population monitoring, population size, predictive modelling, brown bear

\section{IZVLEČEK}

Za upravljanje in ohranjanje populacij prostoživečih živali so potrebni zanesljivi podatki in metode za ocenjevanje njihove številčnosti. Ugotavljanje številčnosti je pri večini vrst drago in zahtevno, zato ga ni mogoče pogosto izvajati. V članku predstavljamo nov pristop, ki smo ga pripravili na primeru rekonstrukcije populacijske dinamike rjavega medveda v Sloveniji v obdobju 19982019. Pristop temelji na kombinaciji dveh ocen njegove številčnosti z neinvazivnimi genetskimi metodami (v letih 2007 in 2015 ) in dolgoletnega niza podatkov monitoringa smrtnosti. Ocena »pomladanske« (t.j. največje letne - po poleganju mladičev) številčnosti rjavega medveda v Sloveniji za leto 1998 znaša 383 (CI: 336-432), za leto 2019 pa 971 osebkov (CI: 825-1161). Povprečna letna stopnja rasti populacije je bila v tem obdobju 4,5 \%. Modelno ocenjena številčnost populacije se je od ugotovljene z genetsko metodo po osmih letih razlikovala le za 7 \%, kar nakazuje, da je pristop zanesljiv oz. so njegovi rezultati za upravljavske namene dovolj kakovostni. Pristop omogoča tudi napovedovanje prihodnje populacijske dinamike pri različnih scenarijih upravljanja in okvirno ocenjevanje ključnih populacijskih parametrov, kot so spolna in starostna sestava, relativna rodnost in naravna smrtnost populacije. Pristop je uporaben tudi za več drugih populacij in živalskih vrst, vendar so zanj potrebni zanesljivi dolgoletni podatki o smrtnosti. Ključne besede: genetske ocene številčnosti populacij, podatki smrtnosti, monitoring populacij, številčnost populacije, napovedno modeliranje, rjavi medved

\section{INTRODUCTION}

\section{UVOD}

Monitoring the dynamics of a given population, namely estimating population size and its changes over time, is central in wildlife management and conservation planning. Endangered species and those that play a large role in ecosystem services often receive more at- tention than more common ones (Yoccoz et al., 2001). Large carnivores also receive attention because they are a conflict prone species that trigger the interest of many stakeholders (Treves, 2009; Ordiz et al., 2013).

Many populations of large carnivores are still severely threatened, and securing their long-term viability continues to be a priority (Ripple et al., 2014). 
At the same time, several large carnivore populations are recovering former ranges, even in human-dominated landscapes (Chapron et al., 2014), which demands up-to-date knowledge on their trends and drivers. The overall mandate for conserving large carnivores is clear today, but this is a challenging task. It implies minimizing potential sources of conflict with people (Redpath et al., 2013) while trying to preserve the inherent characteristics of apex predators (Ordiz et al., 2013).

The brown bear (Ursus arctos) illustrates the case. Some bear populations continue to be at risk of extinction (Ciucci and Boitani, 2008), while others have experienced recent population recoveries (Jerina et al., 2003; Schwartz et al., 2006; Swenson et al., 2017). Conflict arises when a bear causes damage or generates real or perceived threats to people and their livelihoods (Kaczensky et al., 2004; Naves et al., 2018; Støen et al., 2018). Conflict can result in retaliation and, as a matter of fact, humans and their activities cause most large carnivore mortality around the world (Woodroffe and Ginsberg, 1998), with bears being no exception (e.g. Krofel et al., 2012; Bischof et al., 2018).

In Europe, bear management strategies range from the total protection of the most endangered populations to prescribed hunting quotas and culling in larger populations in order to keep population sizes at desired management levels (Swenson et al., 2017; Penteriani et al., 2018), conveniently illustrating bear management in Slovenia. Nevertheless, granting the removal of individuals from a population (derogation from strict protection) requires previous and continuously updated assessments of population size and trends (e.g. EU Habitats Directive, Article 16).

Numerous methods have been used to estimate the population size and trends of large mammals, including brown bears. For instance, some methods have focused on counting specific demographic groups of the population, e.g. bear females with cubs (Knight et al., 1995; Ordiz et al., 2007), others have used sign surveys (Kendall et al., 1992), and some have relied on observation data collected by the public (Kindberg et al., 2009). However, typical characteristics of bears and other large carnivores, e.g. low detectability, large home and distribution ranges, and low population densities, are a challenge for monitoring, and non-invasive genetic methods are currently considered to be the most accurate tool for estimating large carnivore population size (e.g. Bellemain et al., 2005). Today, genetic monitoring is a customary tool for the management of many wildlife species (Stetz et al., 2011) and has been used to monitor brown bear populations in Asia, North America and Europe (e.g. Mowat and Strobeck, 2000; Bellemain et al., 2005; Kendall et al., 2009; Pérez et al., 2014), including Slovenia (Skrbinšek et al., 2019). However, genetic monitoring of large carnivore populations is costly; it often requires the collection, manipulation and analyses of huge amounts of samples, involving many people (Bellemann et al., 2005; Skrbinšek et al., 2019). Therefore, frequent monitoring using genetic analyses is not logistically and financially feasible in many populations. This is a limiting factor for management agencies, which need updated information to set reliable management goals, e.g. to establish annual hunting quotas and to communicate management decisions to stakeholders (Skrbinšek et al., 2019).

On the other hand, good mortality records are available on an annual basis for many terrestrial and aquatic species that are harvested, allowing the reconstruction of population dynamics and assessment of harvest effects (Jerina et al., 2003; Milner et al., 2006; 2011; Carruthers et al., 2014; Gwinn et al., 2015). Mortality records are also used to estimate the magnitude and selectivity of different causes of mortality in large carnivores (Linnell et al., 2010; Raithel et al., 2017), including brown bears in different ecosystems (Bischof et al., 2009; Lamb et al., 2017).

Combining accurate genetic point estimates and long-term mortality data, particularly when the latter are recorded continuously, therefore offers great potential in the study of population dynamics. Here, we present a new methodological approach to reconstructing brown bear population dynamics (size and trend) in Slovenia, Central Europe, for the period 1998-2019, based on the combination of two genetic CMR estimates and long-term continuous records of mortality data. Our approach also allows for the estimation of crucial demographic parameters, such as the age and sex structure of the population. If key demographic parameters (especially birth rate and background mortality) do not change dramatically over time, our approach also has the predictive capacity to forecast the dynamics of the target population in future management scenarios (e.g. under different hunting levels and sex structure).

\section{MATERIALS AND METHODS}

2 MATERIALI IN METODE

\subsection{Study population}

\subsection{Preučevana populacija}

The Dinaric-Pindos brown bear population ranges southwards from Slovenia in the north, through Greece in the south, and includes $>3,000$ bears (Reljić et al., 2018). In the northern part of the Dinaric range in Slovenia and Croatia, bear hunting is one of the main 
management tools to achieve demographic goals, and legal hunting accounts for most bear mortality (Krofel et al., 2012). Almost half of the bears in Slovenia have cross-border home ranges, which requires coordinated population management and monitoring between Slovenia and Croatia (Reljić et al., 2018). However, this study focuses on the Slovenian side for methodological purposes, i.e. to illustrate how the availability of good monitoring data helps describe, reconstruct, and forecast population dynamics.

\subsection{Monitoring data}

\subsection{Podatki monitoringa}

Two non-invasive genetic (based on scats) CMR estimates of the brown bear population size in Slovenia were conducted in 2007 (Skrbinšek et al., 2019) and 2015 (Skrbinšek et al., 2017). Regarding mortality data, the reporting of shot bears and all other mortality cases is mandatory and has been recorded in Slovenia for over 70 years (Jerina et al., 2003). In 1994, the monitoring of bear mortality was upgraded and became one of the regular tasks of the Slovenian Forest Service. Each mortality record includes information on sex, estimated age, numerous body measurements, date, location, and cause of death (see Krofel et al., 2012 for details). If SFS officers cannot determine the cause of death, the National Veterinary Institute examines the carcass. The overall reliability of the data has been adequate since 1998 (Jerina and Krofel, 2012), when all mortality events started to be systematically recorded and included accurate ageing of bears. Therefore, we did not include older records in our analysis. Annual recorded mortality averaged $93 \pm 7$ bears, with an average linear increase of 2.5 bears per year. Bear hunting targets both sexes and also juvenile individuals in Slovenia in an attempt to mimic natural mortality patterns, but females with cubs are protected from hunting. Across the study period, females represented $43 \%$ of recorded mortalities, increasing from $39 \%$ in 1998 to $45 \%$ in 2018. The age of dead bears, which was determined by counting cementum layers on cross-sections of the first premolar (Matson's lab, MT, USA), averaged 2.9 years (Jerina et al., 2018).

Table 1: Population sex structure and size estimates for brown bears in Slovenia according to the two genetic estimates (in 2007 and 2015), after adding the next spring birth rates (see Methods)

\subsection{Estimates of bear population size and birth rates}

2.3 Številčnost in relativna rodnost populacije

Based on intensive noninvasive genetic sampling (collection of scats) and capture-mark-recapture analyses, two late autumn (yearly minimum, i.e. after the main mortality episodes and before the birth of new offspring) population estimates were produced for 2007 (Skrbinšek et al., 2019) and 2015 (Skrbinšek et al., 2017). Bears give birth to cubs in winter, during denning (Friebe et al., 2014). Therefore, to estimate the population size after reproduction in spring, which is relevant for both management and population dynamics modelling, we added birth rates to the late autu$\mathrm{mn}$ estimates. Birth rates of bears have been estimated using different methods in Slovenia, including a) the proportion of cubs $(0+$ year old $)$ in the population based on monitoring at permanent sites (Jerina et al., 2018), b) reconstruction of the population age structure based on age-at-harvest data (Jerina et al., 2018) and c) calibrated population dynamic models, which also provided the sex and age structure of the population (see Jerina et al., 2018 for details). These methods have their own limitations, but although they rely on different assumptions and use independent data, they still yielded remarkably similar birth rate estimates (24-26\%), suggesting that they are likely realistic. We applied the most probable birth rate estimate (24\%; Jerina et al., 2018) to recalculate autumn to spring bear population estimates (spring size in year $\mathrm{X}=$ autumn size in year X-1 / (1-0.24)).

During the reconstruction of the population dynamics, we "calibrated" the matrix population models with the genetic estimates of population sex structure and size in late autumn 2007 and 2015, recalculated to spring estimates for 2008 and 2016, respectively (Table 1).

\subsection{Modeling population dynamics}

\subsection{Modeliranje populacijske dinamike}

The population dynamics was reconstructed using parameters based on estimates of previous studies (Table 2): the initial age structure of the population

Preglednica 1: Ocena spolne sestave in pomladanske številčnosti populacije rjavega medveda v Sloveniji na osnovi rezultatov dveh genetskih cenzusov (2007 in 2015) ob upoštevanju rasti populacije po kotitvi mladičev (glej Metode)

\begin{tabular}{|l|c|c|}
\hline \multicolumn{1}{|c|}{$\mathbf{2 0 0 8}$} & $\mathbf{2 0 1 6}$ \\
\hline spring population size; mean and $95 \% \mathrm{Cl}$ & $558(512-607)$ & $788(723-858)$ \\
\hline $\begin{array}{l}\text { population sex structure - proportion of females; } \\
\text { mean and } 95 \% \mathrm{Cl}\end{array}$ & $59.5 \%(54.5-64.5)$ & $59.5 \%(54.5-64.5)$ \\
\hline
\end{tabular}


Collected data

Variable parameters

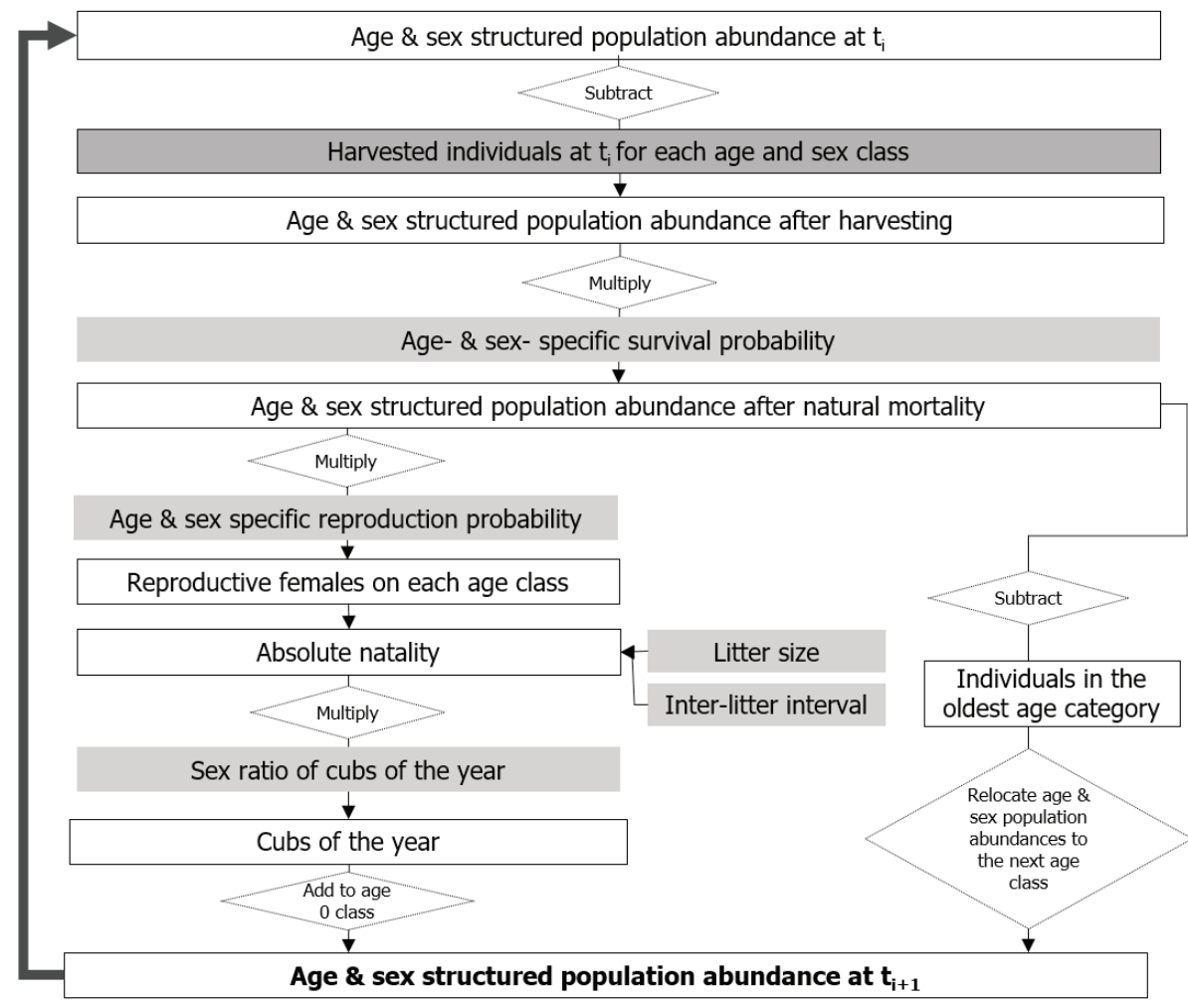

Fig. 1: Schematic representation of the steps performed for modelling brown bear population dynamics in Slovenia. Each step results in the generation of an age and sex structured population. The left arrow shows that the result of each year informs the beginning of the process for the next year. The grey background in the boxes represents data, and the white background is used to denote parameters with uncertainty (summarized in Table 2). Source of figure: Jerina et al., 2018.

in 1998, separately for each sex; sex ratio of the initial population; recorded bear mortality for each year for the period 1998-2018 (frequency, separated by sex and age, from 0 to 21 years); age of primiparity, litter size and inter-litter intervals; cubs-of-the-year sex ratio; sex- and age-specific unrecorded mortality, which was mainly natural mortality, but may include poaching and other sources of unrecorded (background) mortality; and estimates of the size and sex structure of the population in 2008 and 2016 (Table 1). We used parameters obtained in the study area if they were available (i.e. population size estimates, sex structure and litter size). For age and sex-specific survival probabilities, which were not available for our study area, we used values from the Scandinavian brown bear population (Table 2), which is the most similar to the Slovenian population in terms of its demographic trend and management system (both are hunted populations; Bischof et al., 2009; Swenson et al., 2017).

The population size was calculated for each year
Slika 1: Konceptualna shema modeliranja populacijske dinamike rjavega medveda v Sloveniji s prikazanimi opravljenimi računskimi operacijami - koraki. Vsak korak rezultira v spolno in starostno strukturirani matriki populacije $\mathrm{v}$ danem letu. Puščica na levi strani prikazuje, kako so bili rezultati danega leta uporabljeni v naslednjem letu. Okviri s sivim polnilom prikazujejo empirične podatke, prozorni (beli) okviri pa ocenjene ali iz literature povzete parametre (preglednica 2). Slika je povzeta po Jerina in sod., 2018.

after 1998 by a) subtracting recorded (mostly anthropogenic) mortality for the current year (sex- and agespecific), b) multiplying the matrix of surviving individuals by the matrix of sex- and age-specific natural relative mortality (survival) to remove unrecorded mortality, c) calculating the number of reproductive females before denning and number of born cubs in the next year and d) ageing all individuals by one year and adding newborn cubs to move the population into the next year (Fig. 1).

There were limited data for some of the parameters of the model, e.g. accurate information on the initial population size for 1998 was not available. Some of the parameters were fixed (initial age structure separately for each sex, annual and sex- and age-specific recorded mortality), and others varied along an interval of plausible values (Table 2). The real value of these parameters was expected to lie within the provided interval. We used random uniform sampling to build 50,000 sets of experimental values of initial populati- 
Table 2: Description of parameters employed for modelling the population dynamics of brown bears in Slovenia. Allowed values (min-max) show the range of the variables included in the models.
Preglednica 2: Opis parametrov v modeliranju populacijske dinamike rjavega medveda v Sloveniji. Dopustne vrednosti so razponi vrednosti parametrov (min in maks), ki so bili uporabljeni v modelih.

\begin{tabular}{|l|l|c|l|}
\hline \multicolumn{1}{|c|}{ Parameters } & \multicolumn{1}{c|}{ Units } & $\begin{array}{c}\text { Allowed values } \\
\text { (min-max) }\end{array}$ & \multicolumn{1}{c|}{ Data sources } \\
\hline sex structure of population & proportion of females & $(0.545-0.645)$ & Skrbinšek et al., 2017, 2019 \\
\hline cubs-of-the-year sex ratio & proportion of females & $(0.45-0.55)$ & Jerina and Krofel, 2012; Jerina et al., 2018 \\
\hline primiparity (\%) & $\begin{array}{l}\text { proportion of females } \\
\text { of age 3 that are } \\
\text { reproductive }\end{array}$ & $(0-1)$ & Reljić et al., 2018 \\
\hline litter size & individuals & $(1.87-1.95)$ & Jerina et al., 2019, Reljić et al., 2018 \\
\hline interlitter interval & years & $(1.65-2)$ & Reljić et al., 2018 \\
\hline age- \& sex-specific survival probabilities & \multicolumn{3}{|l|}{} \\
\hline survival rate cubs & proportion & $(0.86-0.89)$ & Reljić et al., 2018 \\
\hline $\begin{array}{l}\text { survival rate female year- } \\
\text { lings }\end{array}$ & proportion & $(0.75-0.88)$ & Bischof et al., 2009 \\
\hline $\begin{array}{l}\text { survival rate female suba- } \\
\text { dults }\end{array}$ & proportion & $(0.9-0.96)$ & Bischof et al., 2009 \\
\hline survival rate female adults & proportion & $(0.91-0.95)$ & Bischof et al., 2009 \\
\hline survival rate male yearlings & proportion & $(0.82-0.96)$ & Bischof et al., 2009 \\
\hline survival rate male subadults & proportion & $(0.76-0.87)$ & Bischof et al., 2009 \\
\hline survival rate male adults & proportion & $(0.85-0.92)$ & Bischof et al., 2009 \\
\hline
\end{tabular}

on size estimates for 1998 (range 250-500; Jerina et al., 2018) and values of all variable parameters within a plausible interval (Table 2). Each set of parameters was used to simulate the evolution of the population (total size and sex- and age-structured) for every year between 1998 and 2019. We ran a set of 50,000 simulations (iterations), where each model acted as a competing hypothesis, and we only selected those that fell within the estimated intervals of population size and sex structure according to the estimates of 2008 and 2016 (Table 1). From all simulations that fulfilled these criteria, we calculated the basic statistics of all parameters (size, sex-and age-specific mortality, etc.) to estimate the most probable values for the population, narrowing the initial wider ranges, and calculated the minimum, maximum and average size estimate for each year between 1998 and 2019. Population size and sex structure genetic estimates from 2008 and 2016 thus acted as criteria to separate realistic and unrealistic models, intervals of variable parameters, and combinations of parameters.

\subsection{Estimate of reliability of reconstruction of} population dynamics and potential for predicting future population development

2.5 Zanesljivost rekonstrukcij populacijske dinamike in napovedi prihodnjega razvoja populacije

The described modelling approach can be useful for (i) reconstruction of population dynamics until the first year with a reliable size estimate, (ii) reconstruction between two or more consecutive censuses and (iii) prediction of future population development under different management scenarios (size, sex and age structure of mortality after the last census). Reconstructions between two or more consecutive censuses are "anchored" or fixed from both sides with accurate data, which is why the error of average reconstruction and reconstruction scattering cannot be large (Fig. 1). However, in predictions of future population dynamics, the expected error and scattering estimate (minimum and maximum estimate) increase nonlinearly with distance from the year of the last "calibration" (i.e. the last census year).

To estimate the "expiration date" of the modelling, we attempted to quantify error and estimate scattering relative to the time from the last calibration. Unfortunately, only two size estimates derived from genetic sampling are available for the study population. Nevertheless, we were able to perform validation under a certain assumption. First, we estimated the population size in 1998 (interval estimate) based on the results of both genetic censuses and assumed the estimate was accurate. Next, we generated 50,000 sets of models for the period 1998-2016, and only models that satisfied the criteria of the 2008 genetic sampling were assumed to be realistic, i.e. census results from 2016 were not considered in this step. Finally, the results (average reconstruction and estimate scattering in 2009-2016) of the described models (calibrated only in 2008) were 


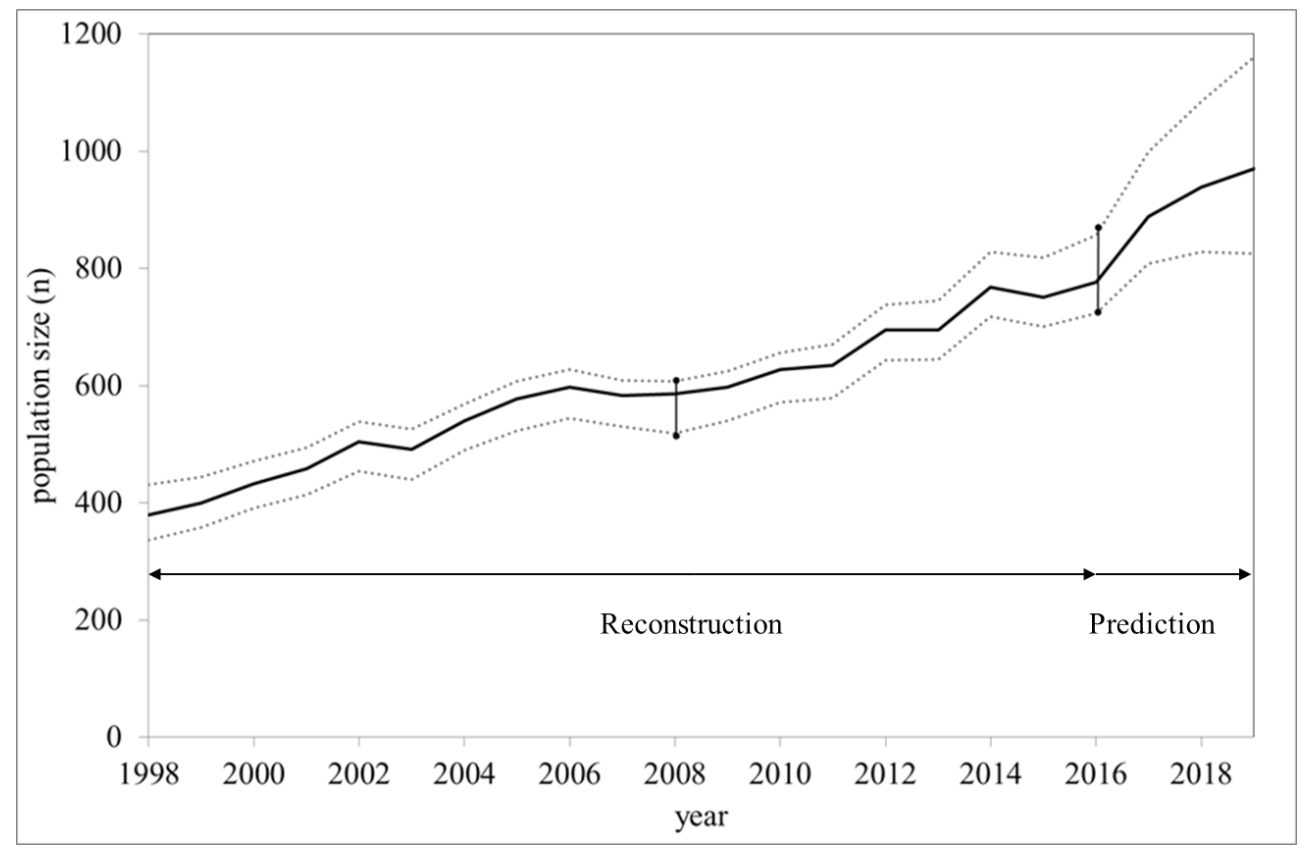

Fig. 2: Reconstruction (up to 2016) and prediction (after 2016) of the annual bear population size in Slovenia in 19982019. The bold line shows the average of all predictions $(\mathrm{n}=$ 148) that accomplished the criteria on population size and sex structure in 2008 and 2016 (years with genetic estimates), and the dotted lines show the minimum and maximum estimates. The vertical lines show the $95 \% \mathrm{CI}$ interval of the population size estimates determined with non-invasive genetic sampling in 2008 and 2016, which we used as lower and upper thresholds to validate the population dynamics models (see Methods).

compared with models calibrated with both genetic estimates (2008 and 2016).

In some of the models calibrated in 2008, the predicted population size increased roughly parallel to the increase in the genetically estimated population size in this period, in some it increased faster (transition from the lower bound of the size interval in the first year to the upper bound in the last year), and in others it increased slower (transition from upper to lower bound). Intuitively, one would expect that models more parallel to the average size increase would be more realistic since the confidence interval in the genetic estimate incorporates the error deriving from uncertainty in assumptions on the distribution of recaptures, violations of spatial enclosure, etc. (sensu Skrbinšek et al., 2017, 2019). Errors due to the described uncertainty were probably similar in both sampling years. True values in two consecutive size estimates are therefore more probably located on the same side of the estimate interval than on the opposite side. Therefore, out of all models located within the interval of the 2008 genetic estimate, we selected those that were closer (more parallel) or departed less from the average size growth during the calibration period (1998-2008). Model
Slika 2: Rekonstrukcija (do leta 2016) in napoved (po 2016) letne številčnosti populacije rjavega medveda v Sloveniji v obdobju 1998-2019. Odebeljene črte prikazujejo povprečne vrednosti vseh modelov ( $\mathrm{n}=148)$, ki so zadostili kriterialnim ocenam številčnosti in spolne sestave, ugotovljene z neinvazivnimi genetskimi metodami leta 2008 in 2016, prekinjene črte pa minimalne in maksimalne vrednosti teh modelov. Navpične črte prikazujejo 95\% intervale zaupanja ocen številčnosti populacije, ugotovljene z neinvazivnimi genetskimi metodami (2008 in 2016), ki so ločevali ustrezne modele $(n=148$ ) od vseh izdelanih (50.000; glej metode).

lambdas were 1.29-1.76 between 1998 and 2008, and the lambda of the average genetic estimates was 1.52 . Models with a lambda of $1.52 \pm 0.05$ (within an arbitrary $10 \%$ of the average size change in 10 years) were selected and analyzed separately.

One of the key reasons for building the population models was to predict population dynamics after the last genetic census, preferably for a few years and for different management scenarios. To assess the usefulness of the models for the intended purpose, we made a prediction for 8 years after the last genetic sampling, i.e. until 2024, using the approaches described above. For 2017 and 2018, we used real data on recorded mortality. For 2019-2024, the data were simulated by making mortality roughly sustainable (stabilizing the population size), with the sex and age composition of the mortality equaling the average of the last 5 years. We ran population models (again, $\mathrm{n}=50,000$ ) for 1998-2024 using the estimated initial size (interval estimate) from the first set of analyses (described in the previous section). We retained the models that fit the estimate intervals of both censuses for sex structure and population size. Out of all fitting models, we selected and separately analyzed models with lamb- 


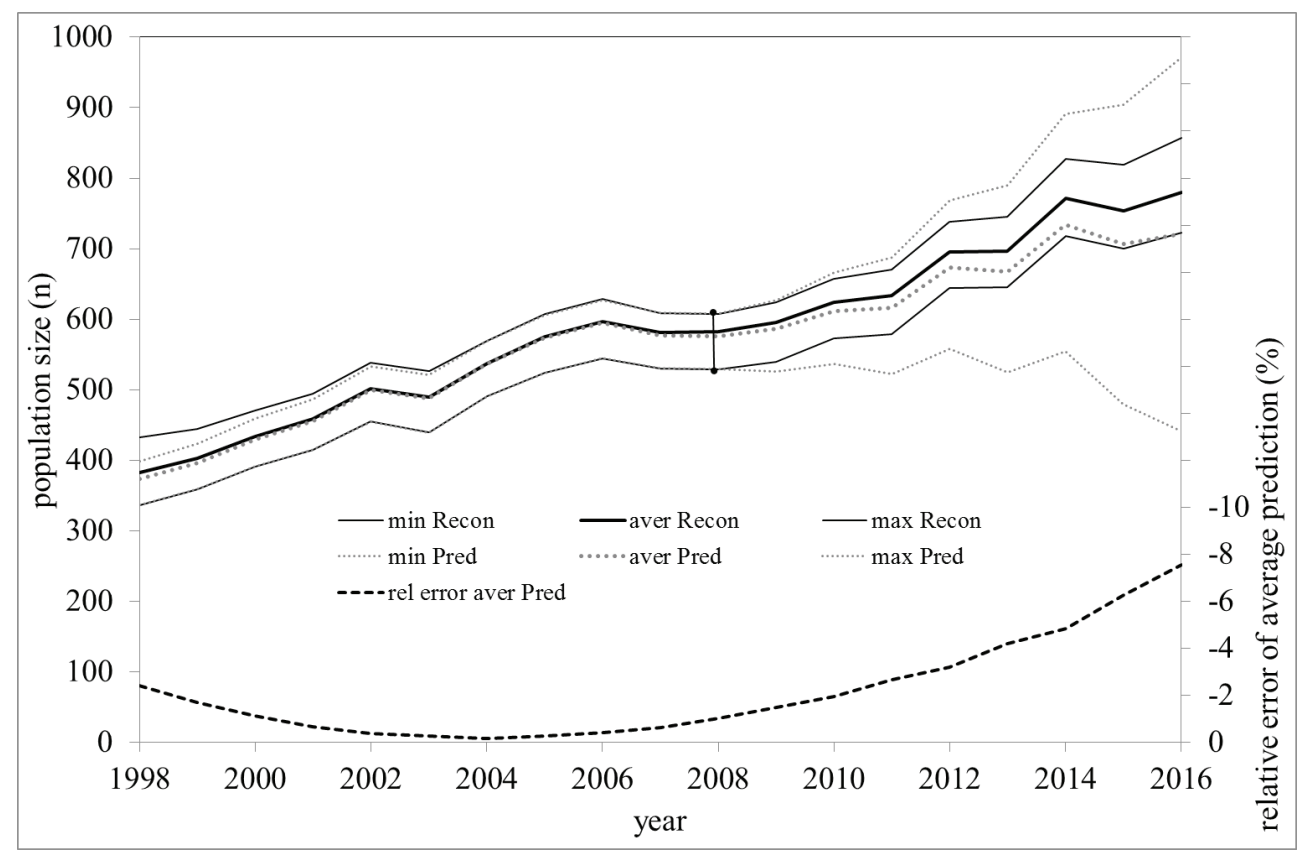

Fig. 3: Evaluation of reliability for predictions of the future bear population size with population models. The bold line (aver Recon) shows average values, and the thin lines show extreme values (min Recon, max Recon) of reconstructed population size models calibrated in 2008 (vertical line) and 2016. The dotted lines forecast values of population size calibrated with the size estimates of 2008, but not in 2016. The bold dotted line in the lower part of the figure (with values on the right vertical axis) shows the relative error (\%) of average predicted values compared to accurate values (reconstructed and fixed based on the population size estimates obtained from genetic sampling in 2008 and 2016).

da "similar" to the average genetic estimate between 2008 and 2016 (i.e. $1.412 \pm 0.05$ ). All analyses were done with a script written in R (R Core Team, 2016) and it is available upon request to the corresponding author.

\section{RESULTS}

\section{REZULTATI}

\subsection{Reconstruction and prediction of annual} population size in the period 1998-2019

3.1 Rekonstrukcije in napovedi letnih ocen številčnosti populacije v obdobju 1998-2019

Of the 50,000 generated population dynamics models for 1998-2019, 148 (0.3\%) provided results within the genetic-based population size and sex structure interval estimates: $7.5 \%$ of the 50,000 models fit the genetic-based population size criterion in 2008, and $2.8 \%$ did so in 2016. Regarding sex structure, 38 $\%$ fitted the structure found in 2008 , and $27 \%$ did so in 2016. The average population size model estimate was 383 (336-432) bears in 1998 and 971 (825-1161) in 2019. The minimum-maximum range predicted by the models was approximately parallel from 1998 until the
Slika 3: Zanesljivost napovedi številčnosti populacije rjavega medveda. Odebeljena črta (aver Recon) prikazuje povprečne in tanke linije skrajne vrednosti (min Recon, max Recon) ocen številčnosti modelov, ki so bili kalibrirani leta 2008 in 2016. Črtkane linije (min, max in aver Pred) pa prikazujejo vrednosti modelov, ki so bili kalibrirani samo leta 2008, ne pa tudi 2016. Odebeljena prekinjena črta na spodnjem delu grafa (vrednosti na desni osi) prikazuje relativno napako (\%) povprečnih napovedanih vrednosti v primerjavi s "pravimi« (točnimi) vrednostmi, ki so bile kalibrirane $\mathrm{z}$ ocenami številčnosti v obeh letih neinvazivnega genetskega monitoringa (tj. 2008 in 2016).

second census (2016), widening proportionately with the widening of genetic size estimates. Between the calibration years (2008 and 2016), the relative width of the interval was stable (13-15\%), but after the last calibration year (2016), it started widening quickly, up to $35 \%$ by 2019 (Fig. 2).

The values of parameters (Table 2) in the initial and selected models were not the same. Models that satisfied the genetic estimate criteria had on average a higher share of primiparous females among 3+ year old females (60 \% vs. $50 \%$ ), a shorter inter-litter interval (1.78 vs. 1.82 years) and lower natural mortality of all categories, except subadult and adult males, than the initial set of models.

\subsection{Reliability of reconstructions and potential for predicting population dynamics}

3.2 Zanesljivost rekonstrukcij populacijske dinamike in napovedi prihodnjega razvoja populacije

Of the 50,000 models for 1998-2008, 585 fit the size and sex structure in 1998 and 2008. Lambdas for 1998-2008 were from 1.29 to 1.76 (average 1.48), lo- 


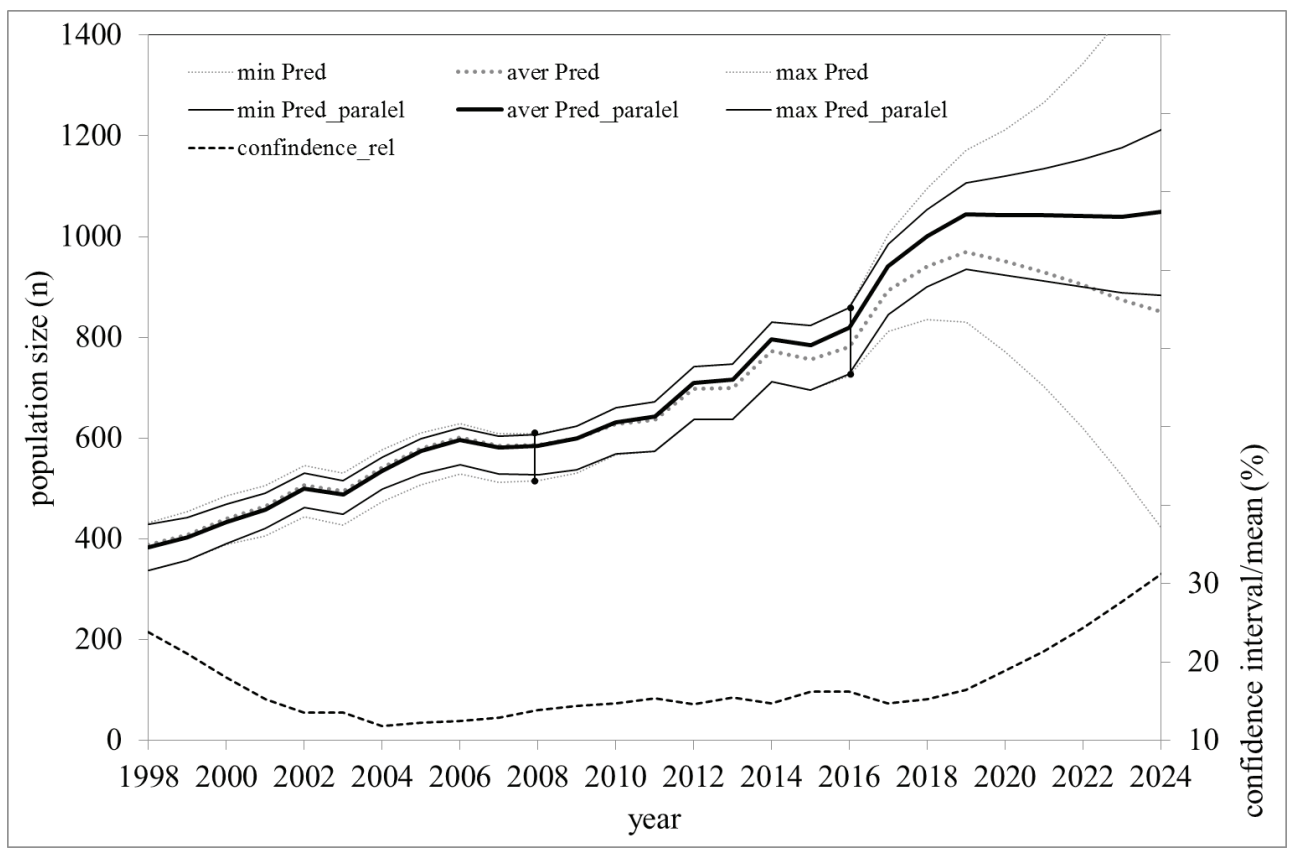

Fig. 4: Predicting the future population size of the brown bear population in Slovenia. The bold line shows the average prediction, and the thin lines show minimum and maximum values for scenarios that predicted population dynamics "parallel" to the actual population dynamics during the calibration period. The dotted lines show all models that satisfied the size and sex structure criteria in 2008 and 2016. The accuracy of the models decreased (the width of the estimated interval increased) with increasing time after calibration (i.e. after 2016). The bold dotted line in the lower part of the figure (with values in the right vertical axis) shows the relative confidence interval (estimate interval width/average estimate). Actual data on sex and age-specific recorded mortality in Slovenia were used in the models until 2018; for 2019-2024, mortality was assumed to be constant (200 removals annually). The vertical lines in 2008 and 2016 point to the years with genetic estimates of population size and sex structure, which we used to calibrate the population models.

wer than the lambda of the average size for this period (1.52). Of the 585 models, 131 had a lambda "similar" (within $1.52 \pm 0.05$ ) to that average. These models forecasted a population size of 721 (441-970) individuals in 2016 , i.e. $7.5 \%$ below the actual value after the genetic-based result. The error of the average estimate increased $\approx$ exponentially with increasing time (number of years) after the model calibration (i.e. after 2008): $-1.5 \%$ in the first year (2009), $-4.2 \%$ in the fourth year (2013) and over $-7 \%$ (i.e. 58 individuals) in 2016. Differences in the forecasted minimum and maximum were larger. The relative width of the estimate interval (interval width/average of estimates) was $13 \%$ in the calibration year and $73 \%$ eight years after the calibration. The maximum forecast for the final year (2016) was $13 \%$ above the upper bound of the genetic-based size estimate interval, and the lo-
Slika 4: Napovedovanje prihodnje populacijske dinamike rjavega medveda $\mathrm{v}$ Sloveniji. Odebeljena črta prikazuje povprečno napoved, tanke črte najnižjo in najvišjo napovedano številčnost za modele, ki v letih kalibracije (tj. med 2008 in 2016) potekajo "vzporedno" z dejanskimi vrednostmi številčnosti in so zato verjetno bolj zanesljive, prekinjene črte pa vse modele (min, max in povprečje), ki so v obeh letih z genetskim cenzusom zadostili kriterijem številčnosti in spolne sestave. Natančnost modelov upada (širina interval zaupanja se povečuje) z oddaljevanjem od leta kalibracije ( $\mathrm{tj}$. po letu 2016). Prekinjena debela črta na dnu grafa prikazuje relativno natančnost modelov (tj. širina interval zaupanja/ povprečje vrednosti). Empirične (dejanske) podatke o smrtnosti smo uporabili za obdobje do 2018. Za obdobje 2019 do 2024 pa smo predpostavili, da znaša letni odvzem 200 medvedov, kar okvirno stabilizira številčnost. Navpične črte v letih 2008 in 2016 prikazujejo intervalne ocene številčnosti, ugotovljene $\mathrm{z}$ neinvazivnimi genetskimi metodami. Te ocene so bile uporabljene za kalibriranje (izbor) modelov.

west was $40 \%$ below the lower bound of that interval (Fig. 3). Similarly, the prediction of future population size (assuming a constant recorded mortality of 200 individuals annually) showed that the estimate interval width increases rapidly with the time from the last calibration and depends on the lambda during the calibration period (2008-2016). All models (regardless of their lambdas) forecasted an average population size of 852 bears for 2024 (range 425-1562). Analyses of models with lambdas similar to those of the average genetic sampling estimates during the calibration period $(1.41 \pm 0.05)$, which are probably more accurate (see Methods for argumentation), forecast a population size of 1050 individuals (885-1212) in 2024. The relative range of estimates (estimate interval width/ average of estimates) of models with selected lambdas increased with the time from the calibration and stood 
at $15 \%$ in the first year after the calibration (2017), $19 \%$ four years after the calibration (2020) and $40 \%$ eight years after the calibration (2024) (Fig. 4).

\section{DISCUSSION}

\section{DISKUSIJA}

Frequent estimation of essential demographic parameters, such as the evolution of population size over time, is crucial for management, particularly for harvested populations (Hare et al., 2011; Bled et al., 2017). For large carnivores, it is not only important for making accurate management decisions, but also for communicating them to the public. For instance, some of the largest populations of large carnivores that are recovering in Europe are still under the carrying capacity, and therefore their demographic trends continue to be positive. There are many cases in which managers aim to slow down or stabilize population trends, mostly to limit conflict with humans, i.e. management implicitly or explicitly sets a "social carrying capacity" below the ecological carrying capacity.

For example, the Scandinavian brown bear population has been increasing in recent decades (Kindberg et al., 2011). In recent years, the number of annual management removals and hunting quotas have increased, and the bear population trend has started to decline (Swenson et al., 2017). To make such management decisions legally, demographically, and sociably defensible, there is a need for up-to-date and reliable population estimates. Even with scientifically-sound population estimates, achieving management goals in terms of population trends is very challenging (Swenson et al., 2017), and failure can cause undesired effects on the target population and a variety of reactions from interested stakeholders.

Our approach fits into such a context, where upto-date demographic information is needed, and the underlying principles of our method are simple. The method is similar to traditional population dynamics modelling, with one essential difference. Classical population dynamic models are notoriously difficult to parametrize in practice due to the absence of quality estimate parameters for the studied population (e.g. natality, age- and sex-specific natural mortality) and are very sensitive to the values of these parameters (e.g. Jerina et al., 2003; Potočnik et al., 2009). As a result, their predictions are typically unreliable. Our approach, however, does not require or even assume accurate values of population parameters, but rather rough interval estimates. These intervals can also be inferred from previous studies and/or study areas and merely have to be wide enough to contain the true va- lues. By verifying marginal conditions (in our case the size and sex structure of the population over two years) and excluding unrealistic models, the method inherently calibrates which combinations of input parameters are suitable and which are not, which is a major advantage over other methods. Models that satisfy the posited criteria can have very different combinations of parameters. The final prediction combines the variance of combinations of parameters in all fitting models and is therefore likely to be robust.

The method makes it possible to reconstruct population dynamics for (i) periods prior to the year of the first population size census, (ii) between two or more censuses and (iii) after the last census. For the brown bear population in Slovenia, we used it for a 21-year period, from 1998 to 2019. The predicted population size was 383 (336-432) in 1998, and it increased by a factor $>1.5$, to 971 animals (825-1161) in 2019; the average annual population growth rate was $4.5 \%$. Several indices suggest that the estimate is good. For example, the estimate for 1998 perfectly matches (383 compared to 391) the age-at-harvest estimate, which is based on completely different assumptions (Jerina at al., 2018; 438 animals assuming a spatially isolated population and 391 assuming the Slovenian population is panmictic with Croatia's, which is closer to reality). In addition, our method excludes part of the interval of values of the initial parameters if they are not realistic. In our case, this exclusion occurred in the age-specific natural mortality of all age categories of both sexes. Values that matched the population size and age structure criteria were on average smaller than the average of the initial values. This was expected because we used estimates from the Scandinavian brown bear population as initial values of natural (background) mortality (Bischof et al., 2009). In Scandinavia, winters are much longer, growing seasons are shorter and living conditions are likely harsher than in Slovenia; accordingly, the expected natural mortality may be higher in Scandinavia. Correction of values of the interval of estimates in the logical direction additionally indicates that our approach is sound. Likewise, the share of reproductive females in the population estimated from the results of our method matched the empirical estimate determined based on long-term intensive bear monitoring at permanent counting sites across the entire brown bear range in Slovenia (described in Jerina et al., 2018).

In this paper, we assumed for outlining the method that the brown bear population in Slovenia is demographically closed. However, this is not realistic because many bears, in particular adult males, have transboundary home ranges (e.g. Reljić et al., 2018). Populati- 
on management and status in one country therefore affects the status of the population in the other country. At the start of the period covered by our study, relative mortality due to hunting was considerably higher in Slovenia than in Croatia, but it subsequently decreased and is now similar in both countries. These management changes may have affected the accuracy of the results. Indeed, our analysis of the reliability of predicting future dynamics showed that models not calibrated in 2016 (they were calibrated in 1998 and 2007) underestimated actual values in the years just prior to 2016. These models were calibrated in a period in which relative hunting mortality in Slovenia was higher and were used to predict dynamics in a subsequent period when hunting pressure was lower. Bears from Croatia probably partially buffered the higher huntingrelated mortality in the initial period, and despite the high mortality, the bear population grew. Our method, like other methods based on recorded mortality, is therefore sensitive to the assumption of spatial enclosure. Nevertheless, in our case the bias was small despite significant differences in management. The predicted population size differed from the actual size by just 7 $\%$ eight years after the calibration year. The bias due to the violation of the assumption about spatial enclosure can also be quantified. For this purpose, within the European LIFE project DinAlpBear (LIFE13 NAT/ SI/0005), which aimed to develop methods for integral transboundary monitoring, we modelled the Slovenian and Croatian bear population at once and then separately modelled its constituent parts in each country to compare differences (Jerina et al., 2018). The results of this analysis were similar to those described above for our study.

We suggest the method we developed has high multi-pronged potential. High-quality mortality records are available for many populations of numerous animal species across the world, and reliable estimates of population size are also increasingly available. The synergy of both sets of data makes it possible to reconstruct the development of population size and structure for each year, resulting in a qualitative and quantitative leap in knowledge about the analyzed populations. Regarding mortality data, the main limitation, aside from quality, is that the majority of total mortality must be recorded. This is not an inherent demand of the method because unrecorded mortality may be included in the model, but if the majority of mortality is unrecorded, the results are probably more uncertain. In practice, the method should be safely applicable for populations in which hunting or other regulated harvesting represent the largest source of mortality, while natural mortality is relatively low and poaching is negligible, which applies to at least some large game species.

The method also provides as a side result the full age and sex matrix of the studied population for each year and improved estimates of input population parameters (e.g. age of primiparity, sex and age specific natural mortality, see Table 2). These estimates can be very useful in research and management. In the DinAlpBear project, for example, we estimated exactly how relative anthropogenic mortality affects brown bear population dynamics, what degree of anthropogenic mortality is sustainable and how sustainability is affected by the sex and age structure of removal, and the relative natality and natural mortality of the population (Jerina et al., 2018). The results are applied in management planning. Even though some of these estimates may be uncertain, e.g. the models may assume excessive natality and natural mortality, whereby both parameters buffer each other, they are often the only available estimates and are useful for many purposes. Although analysis of our data produced very good results, both for the period prior to the first sampling and for the prediction of future population development, fully evaluating the reliability and potential of the method requires analysis of other species and populations, and validation on cases with at least two censuses. Moreover, predictions of future development of population size after the last calibration year are less accurate than reconstructions for the period prior to first reliable size estimate. Differences in accuracy probably occurred because age and sex structure may become unstable in future predictions (e.g. age structure was not calibrated); thus, this is a part of our approach that could be upgraded.

We highlight that using complementarily genetic estimates and mortality records is useful for monitoring population trends, which in turn is needed for the establishment and optimization of population-level monitoring. Specifically, an advantage of our approach is that it prevents the need of frequent (genetic) censuses, which are logistically complex and expensive for species such as large carnivores. We suggest that our approach can prove useful for the Dinaric brown bear population as a whole and for some other wildlife populations, as long as a minimum amount of reliable data and long-term mortality records are available. For trans-border populations, like the Dinaric brown bear population (Reljić et al., 2018), this requires coordinated monitoring and data collection so that management can benefit from common methodological procedures, as suggested elsewhere (e.g. in Scandinavia; Gervasi et al., 2016). Coordinated management is indeed essential across Europe, where eight of the ten 
existing brown bear populations span international borders (Penteriani et al., 2018), and similar situations occur for many other species.

\section{SUMMARY}

\section{POVZETEK}

Za upravljanje in varstvo populacij prostoživečih živalskih vrst so potrebni zanesljivi podatki o trenutnem stanju in dinamiki ciljne populacije, največkrat zlasti o številčnosti in/ali njenih trendih. Ocenjevanje številčnosti je finančno, delovno in organizacijsko zahtevno, kar zlasti velja za prikrite, nočno aktivne vrste, katerih osebki se gibljejo na večjih območjih, kot je značilno za večino vrst divjadi in velikih zveri, vključno z rjavim medvedom. Zato kakovostnih ocen, zlasti za populacije, ki niso zelo majhne, največkrat ni mogoče redno ugotavljati. Od številnih metod za ocenjevanje številčnosti večjih kopenskih živalskih vrst (pregled v Flajšman in sod., 2019), ki temeljijo na intenzivnem terenskem zbiranju podatkov, se vse bolj uveljavljajo molekularno genetske metode, zlasti na osnovi analiz neinvazivnih vzorcev, ki veljajo tudi kot ene bolj zanesljivih. Ta metoda je, npr., standard tudi pri ocenjevanju številčnosti rjavega medveda v Sloveniji. Vendar so se zanjo zaradi velikih stroškov (za eno oceno), zahtevnosti dela in težavnosti ohranjanja motivacije številnih prostovoljcev za zbiranje vzorcev (lovcev in gozdarjev) doslej izvedlo dvakrat, v razmiku osmih let. $V$ takšnem obdobju pa se velikost populacije medveda (lahko) drastično spremeni (glej Jerina in sod., 2018).

Za ocenjevanje številnosti so bile razvite tudi mnoge metode, ki temeljijo na modeliranju procesov populacijske dinamike, ki so sicer računsko intenzivne, vendar se naslanjajo na praviloma že dostopne podatke o populaciji, zato so bistveno cenejše. Točnost takih metod je odvisna od zanesljivosti vhodnih parametrov in predpostavk. Ker točnih ocen vhodnih parametrov pogosto ni na voljo, so rezultati največkrat manj zanesljivi.

V pričujočem članku predstavljamo novo metodo, ki temelji na modeliranju populacijske dinamike s kombiniranjem točkovnih ocen številčnosti (in spolne sestave populacije), intervalnih ocenah vhodnih parametrov ter podatkih sistematičnega monitoringa smrtnosti. Bistvena prednost metode je, da izhodiščne populacijske modele in parametre »kalibrira« s točnimi podatki cenzusov ter napoveduje razvoj populacije na osnovi tako kalibriranih modelov z empiričnimi (zanesljivimi) podatki smrtnosti. Zato so rezultati zanesljivejši kot pri klasičnih pristopih modeliranja, obenem pa je metoda bistveno cenejša, kot če bi uporabljali pogostejše genetsko ocenjevanje velikosti populacije.
Metoda torej združuje prednost obeh pristopov.

Metodo smo razvili in jo uporabili na primeru modeliranja populacijske dinamike rjavega medveda $\mathrm{v}$ Sloveniji v obdobju 1998-2019, in sicer na osnovi dveh (leto 2007 in 2015) genetsko molekularnih ocen številčnosti (in spolne sestave), vsakoletnih podatkov evidentirane smrtnost (celotno obdobje 1998-2019; spol in starost) in okvirnih ocen, ključnih populacijskih procesov, povzetih iz domačih ali tujih raziskav (starost ob prvi reprodukciji, velikost legla, spolno in starostno specifična naravna oz. neevidentirana smrtnost, starostna sestava populacije ločeno za vsak spol). Vsak niz modelov modelira razvoj populacije $v$ izbranem obdobju na osnovi konstantnih izhodiščnih parametrov (razen smrtnosti), ki so naključno izbrani znotraj intervala možnih vrednosti. Vse nize modelov, ki so podali ocene številčnosti (in v našem primeru spolne sestave) skladno z genetskimi ocenami iz obeh let, smo privzeli kot uporabne, druge pa smo zavrgli. $\mathrm{Na}$ osnovi $3 \times 50.000$ nizov modelov smo: i) rekonstruirali populacijsko dinamiko rjavega medveda v obdobju 1998-2019, ii) ocenili točnost pristopa, iii) preskusili uporabnost pristopa za napovedovanje razvoja populacije po letu zadnje kalibracije (tj. v letu 2015).

Ocena številčnosti rjavega medveda v Sloveniji za leto 1998 (po poleganju, tj. spomladi po prihodu iz brlogov) je 383 (CI: 336-432), za leto 2019 pa 971 osebkov (CI: 825-1161). Povprečna letna stopnja rasti populacije je bila v preučevanem obdobju 4,5 \%. Z vidika validacije rezultatov pristopa velja poudariti zlasti: (i) modelno ocenjena številčnost populacije se je od ugotovljene z neinvazivnimi genetskimi metodami po osmih letih razlikovala le za 7 \%; (ii) ocena številčnosti v letu 1998 je skoraj identična neodvisni oceni, ugotovljeni s t. i. age-at harvest pristopom; (iii) »kalibrirani« parametri so bližje pričakovanim od inicialnih, ki smo jih povzeli iz tujih raziskav. Vse to nakazuje, da je naš pristop zanesljiv oz. so njegovi rezultati za upravljavske namene dovolj kakovostni. Z oddaljevanjem od leta zadnje kalibracije (torej empirične točkovne ocene številčnosti) so napovedi populacijskih modelov vse manj natančne (širši interval zaupanja), kar zmanjšuje njihovo uporabnost. Na osnovi dobljenih rezultatov in upoštevaje, da so pri nas na voljo tudi drugi neodvisni monitoringi (npr. populacijski trendi številčnosti na osnovi štetja na stalnih števnih mestih), ocenjujemo, da so modelne ocene številčnosti dovolj zanesljive za obdobje do osem let po zadnji kalibraciji, torej je $\mathrm{z}$ intenzivnimi molekularnimi cenzusi rjavega medveda smiselno nadaljevati v (največ) osemletnih intervalih.

Pristop, ki smo ga razvili, je po naši oceni lahko uporaben za številne populacije različnih živalskih 
vrst. Vendar so za njegovo izvedbo nujni vsaj dve (čim bolj zanesljivi) oceni številčnosti (še bolje tudi drugih parametrov) in zanesljivi podatki o smrtnosti (nepretrgani dolgoletni monitoringi). Slednji so na voljo predvsem pri nekaterih vrstah velikih sesalcev, s katerimi se intenzivno upravlja oz. je lov glavni vir smrtnosti, vzpostavljen sistem evidentiranja smrtnosti živali pa je učinkovit (ni krivolova, obstaja celostno javljanje in vodenje podatkov o odvzetih živalih, smrtnost zaradi naravnih dejavnikov pa je mnogo manjša od antropogene smrtnosti).

\section{ACKNOWLEDGMENTS}

\section{ZAHVALA}

Preliminary analyses were carried out within the EU-funded project LIFE13 NAT/SI/0005, which also funded AO. KJ was partially supported through funding from the Slovenian Research Agency (P4-0059 and J47362). We would like to thank the personnel from the Slovenia Forest Service and Hunters Organization of Slovenia for data sharing and fruitful cooperation. We also thank two reviewers for their constructive comments.

\section{REFERENCES}

\section{VIRI}

Bellemain E., Swenson J.E., Tallmon D., Brunberg S., Taberlet P. 2005. Estimating population size of elusive animals with DNA from hunter-collected feces: four methods for brown bears. Conservation Biology, 19: 150-161.

Bischof R., Bonenfant C., Rivrud I.M., ..., Swenson J.E. 2018. Regulated hunting re-shapes the life history of brown bears. Nature Ecology and Evolution, 2: 116-123.

Bischof R., Swenson J.E., Yoccoz N.G., Mysterud A., Gimenez O. 2009. The magnitude and selectivity of natural and multiple anthropogenic mortality causes in hunted brown bears. Journal of Animal Ecology, 78: 656-665.

Bled F., Belant J.L., Van Daele L.J., Svoboda N., Gustine D., Hildebrand G., Barnes V.G. 2017. Using multiple data types and integrated population models to improve our knowledge of apex predator population dynamics. Ecology and Evolution, 7: 9531-9543.

Carruthers T.R., Punt A.E., Walters C.J., MacCall A., McAllister M., Dick E.J., Cope J. 2014. Evaluating methods for setting catch limits in data-limited fisheries. Fisheries Research, 153: 48-68.

Chapron G., Kaczensky P., von Arx M., ..., Boitani L. 2014. Recovery of large carnivores in Europe's modern human dominated landscapes. Science, 346: 1517-1519.

Ciucci P., Boitani L. 2008. The Apennine brown bear: a critical review of is status and conservation problems. Ursus, 19: 130-145.

Flajšman K., Fležar U., Pokorny B., Jerina K. 2019. Pregled metod za določanje številčnosti prostoživečih parkljarjev. Acta Silvae et Ligni, 118: 13-27.

Friebe A., Evans A., Arnemo J.M., ..., Zedrosser A. 2014. Factors affecting date of implantation, parturition, and den entry estimated from activity and body temperature in free-ranging brown bears. PLoS One, 9: e101410. https://doi.org/10.1371/journal. pone. 0101410
Gervasi V., Brøseth H., Gimenez O., Nielsen E., Odden J., Flagstad Ø., Linnell J.D.C. 2016. Sharing data improves monitoring of transboundary populations: the case of wolverines in central Scandinavia. Wildlife Biology, 22: 95-106.

Gwinn D.C., Allen M.S., Johnston F.D., Brown P., Todd C., Arlinghaus R. 2015. Rethinking length-based fisheries regulations: the value of protecting old and large fish with harvest slots. Fish and Fisheries, 16: 259-281.

Hare M.P., Nunney L., Schwartz M.K., Ruzzante D. 2011. Understanding and estimating effective population size for practical application in marine species. Conservation Biology, 25: 438-449.

Jerina K., Debeljak M., Džeroski S., Kobler A., Adamič M. 2003. Modeling the brown bear population in Slovenia: a tool in the conservation management of a threatened species. Ecological Modelling, 170: 453-469.

Jerina K., Krofel M. 2012. Monitoring odvzema rjavega medveda iz narave v Sloveniji na osnovi starosti določene s pomočjo brušenja zob: obdobje 2007-2010. Ljubljana, Biotehniška fakulteta, Oddelek za gozdarstvo in obnovljive gozdne vire: $33 \mathrm{pp}$.

Jerina K., Polaina E., Huber Đ., Reljić Đ., Bartol M., Srbinšek T., Jonozovič M. 2018. Reconstruction of brown bear population dynamics in Slovenia and Croatia for the period 1998-2018. LIFE DINALP BEAR Project (LIFE13 NAT/SI/0005): 46 pp.

Kaczensky P., Blažič M., Gossow H. 2004. Public attitudes towards brown bears (Ursus arctos) in Slovenia. Biological Conservation, 118: 661-674.

Kendall K.C., Metzgar L.H., Patterson D.A., Steele B.M. 1992. Power of sign surveys to monitor population trends. Ecological Applications, 2: 422-430.

Kendall K.C., Stetz J.B., Boulanger J., McLeod A., Patkeau D. 2009. Demography and genetic structure of a recovering grizzly bear population. Journal of Wildlife Management, 73: 3-17.

Kindberg J., Ericsson G., Swenson J.E. 2009. Monitoring rare or elusive large mammals using effort-corrected voluntary observers. Biological Conservation, 142: 159-165.

Kindberg J., Swenson J.E., Ericsson G., Bellemain E., Miquel C., Taberlet P. 2011. Estimating population size and trends of the Swedish brown bear (Ursus arctos) population. Wildlife Biology, 17: 114-123.

Knight R.R., Blanchard B.M., Eberhardt L.L. 1995. Appraising status of the Yellowstone grizzly bear population by counting females with cubs-of-the-year. Wildlife Society Bulletin, 23: 245-248.

Krofel M., Jonozovič M., Jerina K. 2012. Demography and mortality patterns of removed brown bears in a heavily exploited population. Ursus, 23: 91-103.

Lamb C.T., Mowat G., McLellan B.N., Nielsen S., Boutin S. 2017. Forbidden fruit: human settlement and abundant fruit create an ecological trap for an apex omnivore. Journal of Animal Ecology, 86: 55-65.

Linnell J.D.C., Broseth H., Odden J., Nilsen E.B. 2010. Sustainably harvesting a large carnivore? Development of eurasian lynx populations in Norway during 160 years of shifting policy. Environmental Management, 45: 1142-1154.

Milner J.M., Bonenfant C., Mysterud A., Gaillard J.M., Csanyi S., Stenseth N.C. 2006. Temporal and spatial development of red deer harvesting in Europe: biological and cultural factors. Journal of Applied Ecology, 43: 721-734.

Milner J.M., Bonenfant C., Mysterud A. 2011. Hunting Bambi-evaluating the basis for selective harvesting of juveniles. European Journal of Wildlife Research, 57: 565-574.

Mowat G., Strobeck C. 2000. Estimating population size of grizzly bears using hair capture, DNA profiling, and mark-recapture analysis. Journal of Wildlife Management, 64: 183-193. 
Naves J., Ordiz A., Fernández-Gil A., ..., Delibes M. 2018. Patterns of brown bear damages on apiaries and management recommendations in the Cantabrian Mountains, Spain. PLoS One, 13: e0206733. https://doi.org/10.1371/journal.pone.0206733

Ordiz A., Bischof R., Swenson J.E. 2013. Saving large carnivores, but losing the apex predator? Biological Conservation, 168: 128133.

Ordiz A., Rodríguez C., Naves J., ..., Swenson J.E. 2007. Distance-based criteria to identify minimum number of brown bear females with cubs in Europe. Ursus, 18: 158-167.

Penteriani V., Huber Đ., Jerina K., ..., Dalerum F. 2018. Trans-boundary and transregional management of a large carnivore: managing brown bears across national and regional borders in Europe. In: Hovardas T. (ed.). Large carnivore conservation and management: human dimensions. Routledge: 291-313.

Pérez T., Naves J., Vázquez J.F., ..., Domínguez A. 2014. Estimating the population size of the endangered Cantabrian brown bear through genetic sampling. Wildlife Biology, 20: 300-309.

Potočnik H., Skrbinšek T., Kos I. 2009. The reintroduced Dinaric lynx population dynamics in PVA simulation: the 30 years retrospection and the future viability. Acta Biologica Slovenica, 52, 1: 3-18.

Raithel J.D., Reynolds-Hogland M.J., Koons D.N., Carr P.C., Aubrey L.M. 2017. Recreational harvest and incident-response management reduce human-carnivore conflicts in an anthropogenic landscape. Journal of Applied Ecology, 54: 1552-1562.

Redpath S.M., Young J., Evely A., ..., Gutiérrez R.J. 2013. Understanding and managing conservation conflicts. Trends in Ecology and Evolution, 28: 100-109.

Reljić S., Jerina K., Nilsen E.B., Huber Đ., Kusak J., Jonozovič M., Linnell J.D.C. 2018. Challenges for transboundary management of a European brown bear population. Global Ecology and Conservation, 16: e00488. https://doi.org/10.1016/j.gecco.2018.e00488

Ripple W.J., Smith D.W., Estes J.A., ..., Wirsing A.J. 2014. Status and ecological effects of the world's largest carnivores. Science, 343: 1241484. https://doi.org/10.1126/science.1241484
Schwartz C., Haroldson M., White G., ..., Servheen C. 2006. Temporal, spatial, and environmental influences on the demographics of grizzly bears in the Greater Yellowstone Ecosystem. Wildlife Monographs, 161: 1-68.

Skrbinšek T., Jelenčič M., Luštrik R., ..., Kos I. 2017. Genetic estimates of census and effective population sizes of brown bears in Northern Dinaric Mountains and South- Eastern Alps. LIFE DINALP BEAR Project (LIFE13 NAT/SI/0005): 65 pp

Skrbinšek T., Luštrik R., Majić-Skrbinšek A., ..., Trontelj P. 2019. From science to practice: genetic estimate of brown bear population size in Slovenia and how it influenced bear management. European Journal of Wildlife Research, 65: 29. https://doi. org/10.1007/s10344-019-1265-7

Stetz J.B., Kendall K.C., Vojta C.D. 2011. Genetic monitoring for managers: a new online resource. Journal of Fish and Wildlife Management, 2: 216-219.

Støen O-G., Ordiz A., Sahlén V., ..., Swenson J.E 2018. Brown bear (Ursus arctos) attacks resulting in human casualties in Scandinavia 1977-2016; management implications and recommendations. PLoS One, 13: e0196876. https://doi.org/10.1371/journal. pone.0196876

Swenson J.E., Schneider M., Zedrosser A., Söderberg A., Franzén R., Kindberg J. 2017. Challenges of managing a European brown bear population; lessons from Sweden, 1943-2013. Wildlife Biology, 2017(4): wlb.00251. https://doi.org/10.2981/wlb.00251

Treves A. 2009. Hunting for large carnivore conservation. Journal of Applied Ecology, 46: 1350-1356.

Woodroffe R., Ginsberg J.R. 1998. Edge effects and the extinction of populations inside protected areas. Science, 280: 10-13.

Yoccoz N., Nichols J.D., Boulinier T. 2001. Monitoring of biological diversity in space and time. Trends in Ecology and Evolution, 16: 446-453. 
